\title{
Antipower, Agency, and the Republican Case for Global Institutional Pluralism
}

\author{
Terry Macdonald, School of Social and Political Sciences, \\ University of Melbourne
}

\section{Introduction}

One notable contribution made by recent work in republican theory has been its push to shift the focus of normative political analysis away from the structure of institutions that distribute social goods, and towards the structure of power relationships among individuals and groups within a social order. The republican political ideal prescribes combating power within social relationships that takes a particular pernicious form generally called "arbitrary," or "alien" - in which control is exercised by one actor over another without appropriate political endorsement or contestability. ${ }^{1}$ This focus on power within republican theory equips it well to contribute to contemporary debates about institution building in the global domain, where dynamics of power relationships are prominent features of the political landscape.

Republican theory's contribution to debates about international institutions has been constrained, however, by the fact that its normative institutional principles have mostly been applied to structures and policies of constitutional sovereign states. Few are

\footnotetext{
${ }^{1}$ See Philip Pettit, Republicanism: A Theory of Freedom and Government (Oxford: Oxford University Press, 1999); Pettit, "A Republican Law of Peoples," European Journal of Political Theory 9, no. 1 (2010): 70-94. Cf. Pettit, "The Republican Law of Peoples: A Restatement" (this volume).
} 
persuaded that the same institutional models that enact republican ideals at the level of the state could effectively or legitimately be replicated straightforwardly on a global scale. Yet there is no straightforward way to apply republican institutional principles to some global institutional subject - analogous, say, to the application of some established principles of socio-economic justice to a global rather than a statist "basic structure" or "institutional scheme."2 A key reason for this is that republican state institutions are often characterised as themselves constitutive of the normative ideal of non-domination, as distinct from being merely subjects to which its principles can be applied. ${ }^{3}$ As such, it is not altogether clear how normative standards can be drawn out from republican thought to critique statist institutional models, or to guide the development of alternative institutions more suitable for the global political sphere.

Before the republican political ideal can be extended systematically to the global domain, it is therefore necessary to reformulate our conception of the ideal itself, in order to open it to a wider range of institutional applications across varying political contexts. Reformulating the republican ideal in this way directs us to undertake a twofold theoretical analysis. First, we can formulate the ideal in terms that are abstracted from state-level institutional models, so that we have some critical tools with which to devise and evaluate institutional alternatives to statism. Second, with these theoretical tools in hand, we can then consider how this ideal could be institutionally constituted or promoted under the particular empirical circumstances of contemporary global politics. These are the two central tasks that I undertake in this chapter.

\footnotetext{
${ }^{2}$ See for example Thomas Pogge, Realizing Rawls (Ithaca: Cornell University Press, 1989).

${ }^{3}$ Pettit characterizes non-domination as "institutionally constituted" in Republicanism, pp. 106-7.
} 
A promising starting point for such a theoretical reformulation of the ideal of nondomination is Philip Pettit's concept of "antipower," 4 understood as a set of active social forces that serve to counteract, contain, and regulate 'public' political power. This concept is promising for these purposes, since it is abstracted from any specific statist institutional forms. This idea of antipower is prominent only in one of Pettit's early essays on republicanism, and there its sociological character is a little mysterious; it is unclear whether it is best understood as a type of institution, a kind of institutional function, or a form of social agency. In Pettit's subsequent writing on the republican ideal, talk of antipower is largely abandoned in favor of talk of non-domination as an institutionally constituted political good.

In my analysis here, however, I proceed with the view that the earlier concept of antipower is in fact a very useful one for thinking about the problems of republican institution building, if it is put to work in the right kind of way. More specifically, I propose that antipower can be most helpfully understood as a form of social agency with a special political function (partially but not wholly constituted by the right kind of political institutions) - and that alongside the partner concept of public power can form the basis of a functional conception of non-domination that can usefully guide prescriptions for institution building within the global political domain.

In what follows, I develop this general idea about antipower by presenting a functional account of group agency, followed by a functional conception of nondomination in which functional agencies of antipower - alongside those of public power - play constitutive roles. With these theoretical tools in hand, I then consider the

\footnotetext{
${ }^{4}$ Pettit, "Freedom as Antipower," Ethics 106, no. 3 (1996): 576-604.
} 
implications of this functional and agency-based account of the republican ideal for practical questions about the design and development of global institutions. I argue that antipower, on the functional agency account, is not wholly institutionally constituted; rather, its agency is constituted in part through background material and cultural structures. In order for political institutions to foster non-domination, they must therefore be designed in a way that reflects and accommodates background material and cultural structures, so that the functional agency of "antipower" can develop and flourish within them. Given present "pluralist" global background structures, I argue that republican political institutions must also adopt a loose and pluralist character - with important implications for some contemporary institutional dilemmas concerning practices of global governance, accountability, and democracy.

\section{A Functional Account of Group Agency}

My account of the ideal of non-domination as constituted by the interplay of special functional forms of social agency depends upon accepting a more general functional conception of group agency itself. I conceive of group agents as functionally constituted, in the sense that we can see certain kinds of groups to function as agents somewhat autonomously from the agency of their individual members. It is therefore important to begin by sketching the key elements of this conception of group agency.

There is now a wide (and growing) philosophical literature on the topics of both collective action and collective agency. For the present purposes I draw my account of group agents directly from the recent work of Christian List and Philip Pettit - which articulates a conception of group agency that highlights characteristics most salient to the 
kind of normative political analysis I wish to undertake here. ${ }^{5}$ This salience is to some degree by design, since this work on group agency is very closely aligned and has been developed in conjunction with Pettit's work on the political philosophy of republicanism, as well as List's work on the philosophy of democracy; their theoretical model of group agency has important applications in research on both of these political ideals.

I cannot rehearse here in full all salient details of this sophisticated philosophical account of group agency, but for the present purposes it is sufficient to note some features of the account that provide grounds for understanding the functional roles I want to attribute to group agents (of public power and antipower respectively) within my reading of the republican political ideal. The central point to emphasize, in doing so, is that group agents share in common with individual agents the same basic characteristics that together constitute the goal-seeking function of agency in general. In simple terms, the three features constitutive of an agent are: beliefs about what its environment is like; desires regarding how it would like things in that environment to be; and the capacity to process these beliefs and desires, leading it to intervene in the environment to better satisfy its desires. ${ }^{6}$ In order for an agent to intervene successfully in its environment in pursuit of its desires (or as we often say more plainly, to advance its goals), it must also meet some adequate standards of functioning, which are commonly called "standards of

${ }^{5}$ List and Pettit have both published widely on problems of group decision and agency, but here I draw most directly on their recent book-length treatment of the topic: Christian List, and Philip Pettit, Group Agency: The Possibility, Design, and Status of Corporate Agents (Oxford: Oxford University Press, 2011).

${ }^{6}$ To put these three features more technically, agents are systems that incorporate: "representational states that depict how things are in the environment"; "motivational states that specify how it requires things to be in the environment"; and "the capacity to process its representational and motivational states, leading it to intervene suitably in the environment whenever that environment fails to match a motivating specification" (ibid., p. 20). 
rationality," in each of the three dimensions: formation of beliefs in accordance with reality; coherence and viability of desires; and the efficacy of interventions (through action) with respect to these beliefs and desires. ${ }^{7}$ As List and Pettit put it, a group agent

is organized so as to seek the realization of certain motivations in the world and to do so on the basis of certain representations about what that world is like. When action is taken in the group's name - say, by its members or deputies - this is done for the satisfaction of the group's desires, and according to the group's beliefs. $^{8}$

It is important to emphasize that this account of group agency is a functional one. Although group agents function analogously to individual agents, there is no claim that they exist in any way independently from their individual members; that is, they are not any kind of metaphysically mysterious entities, incompatible with methodological individualism in social science. Rather, they are constituted by a collection of individual agents organised in such a way as to meet these conditions and standards of functioning that are definitive of agency. The manner in which groups of individuals can meet these conditions and standards is complex and contextually variable, and is dependent on various kinds of "joint intentions" being in place among members of the group - often including the joint intention to act as a group - as well as other institutional and noninstitutional conditions being met. It is beyond the scope of this chapter to elaborate or

\footnotetext{
${ }^{7}$ List and Pettit call these standards "attitude-to-fact," "attitude-to-attitude," and "attitude-to-action" standards of rationality (ibid., p. 24).

${ }^{8}$ Ibid., p. 32.
} 
address the various philosophical difficulties with explaining how groups of individuals can meet these conditions and standards (though in the next section I consider some aspects of these difficulties as they bear upon the question of the limits of institutional design in constituting group agents). In general, though, I assume in what follows here that these difficulties can be overcome, and that there are robust philosophical grounds for viewing group agents as real functional entities in the social world. ${ }^{9}$

This functional understanding of what group agents are helps us to grasp why it is important to recognise group agents as distinct social entities within the conceptual frameworks of our political ideals, even though such group agents do not exist independently from the individuals that make them up - that is, even though the ontological relationship of group attitudes and actions to those of their individual members is one of supervenience rather than independence. The importance of recognising group agents as autonomous from individuals arises from the fact that - from the perspective of the individuals who encounter group agents in social life - they appear to those who interact with them to function more or less autonomously from these individuals, and can be most effectively engaged with if they are understood and treated as such. ${ }^{10}$ As List and Pettit put this point:

[t]he agency of the group relates in such a complex way to the agency of individuals that we have little chance of tracking the dispositions of the group agent, and of interacting with it as an agent to contest or interrogate, persuade or

\footnotetext{
${ }^{9}$ List and Pettit provide some detailed arguments for the validity of this assumption in ibid., chapters two and three.

${ }^{10}$ By "effective" here I am referring to effectiveness relative to the goals of individual agents.
} 
coerce, if we conceptualize its doings at the individual level. ... [W]e will be unable to recognize the kind of group agent we have in mind as an agent, and to predict how it is likely to perform and what we can do to affect it, if we keep our gaze fixed at the level of individuals. We will fail to see the wood for the trees. ${ }^{11}$

As List and Pettit emphasise, the sense in which group agents are functionally autonomous from their individual members is epistemological rather than ontological, but the claim of functional autonomy is no less important for that. The features of social reality that should be incorporated within our political ideals are those that the actors whose relationships the ideal aims to regulate can perceive and engage with at a political level; political ideals, in this sense, need to be formulated in terms of political rather than metaphysical conceptions of social ontology. And for this purpose, the conception of group agents as functionally constituted autonomous actors within the social world clearly fits the bill.

\section{Public Power, Antipower, and the Functional Conception of Non-Domination} With this general functional account of group agency in hand, we can move now to an elaboration of the ideas of public power and antipower as denoting special functional forms of group agency within a political order. We can understand these as performing not only the general functions characteristic of agency, but also the more specialized functions of advancing common goods (in the case of public power) and counteracting the choice-constraining effects of public power with participatory and countervailing

${ }^{11}$ List and Pettit, Group Agency, p. 76. 
collective political action (in the case of antipower). When operating appropriately in conjunction, it is my claim that these together perform the overarching function that constitutes the political good of non-domination.

To explain these claims in more detail, it will help to begin by characterizing the political good of non-domination - and the functions of public power and antipower that together constitute it - in pragmatic terms: as a good in virtue of serving as a functional remedy for a particular (characteristically "political") social problem. This problem arises from the parallel operation of two basic roles in which individuals encounter and engage with powerful group agents in the course of their social lives. The first of these roles is that of participants, or "members," in group agencies. ${ }^{12}$ The participation characteristic of membership here can take the form either of participation in the creation and authorization of a group agent with specified functions and powers, or direct participation in the decision-making and action of the group agent at an operational level - or both. Here, individuals encounter group agency from the 'inside', so to speak, via involvement in the formation of collective intentions and actions - that is, the channelling of individual interests into the articulation and pursuit of common goals. ${ }^{13}$

The second of these roles is that of subjects of group agents. In this capacity individuals are affected and constrained by the power of a group agent, whose intentions and actions, as previously established, will have some degree of autonomy from those of individuals - including individual members as well as non-members. While the autonomy

\footnotetext{
12 I talk about "members" and "participants" here in roughly the senses in which List and Pettit describe group membership, in ibid., pp. 35-6.

${ }^{13}$ Viewing non-domination is a political ideal in this pragmatic sense is distinct from the consequentialist sense in which Pettit characterises it as a political ideal - namely, as "a value that the state ought to try and advance." (Pettit, Republicanism, p. 92)
} 
of the intentions and actions of group agents from those of non-member individuals is straightforwardly evident, the sense in which they are autonomous from those of member individuals is more complex, and depends on the fuller philosophical account of how a group agent can come to acquire its functional autonomy from its individual members. Leaving aside complex philosophical problems of preference aggregation and group rationality, ${ }^{14}$ I simply assume this autonomy for the present purposes. What is important to emphasise here is that when in the role of subjects, individuals encounter group agents from the 'outside', so to speak - in the sense that they find themselves affected by decisions and actions that they have not as individuals intended.

In some political contexts an individual will engage with a powerful group agent in both roles at once. To illustrate this with the familiar example of a closed and ideally constituted democratic state, an individual will engage with the agency of the state in both roles: as participant, in the role of democratic citizen participating in the authorization and, to a lesser extent, the collective decision-making of the group agent of the state; and as subject to the significant powers the state possesses to execute its decisions. In other contexts, the roles of participant and subject can come apart. To take again the example of the group agency of the state, an individual can be, and often is, subject to state power without also being incorporated as a participant in the collective decision-making and action of the state as group agent. This can be the case either for legal citizens or non-citizens, depending on the forms of political participation in state decision-making that are available, and the extent to which the interests of either are represented in state decision-making, in a particular context. Individuals can also

\footnotetext{
${ }^{14}$ An account of this is elaborated in List, Group Agency, chs. 2, 3.
} 
encounter powerful group agents of other non-state types - such as economic corporations, and non-profit "civil society" actors of various kinds - in roles of either participant or subject, and these relationships also form an important part of the social order in which individuals live.

The basic political problem that results from the parallel operation of these two kinds of roles is the following. On the one hand, participation in the creation, authorisation and operation of functionally effective group agencies can produce many benefits for the individuals involved. The goods that can be produced for individuals by acting collectively to authorise or directly operate group agents can vary according to individuals' preferences and circumstances, but important examples of such goods are the provision of physical security, the production and distribution of new social goods, or as in the case of an ideal republican state agency - the promotion of the political good of non-domination itself. As a result, there are good reasons for individuals to continue to choose to create and enable group agents to advance their goals, and thus there are good reasons too for rejecting any political ideal that recommends forms of political "nonintervention" that are incompatible with the persistence of robust forms of collective action and agency within the social order.

On the other hand, however, the creation and maintenance of powerful agencies brings the persistent risk that the group agents which individuals have constituted to advance their common goals will become alienated from, and fail to act effectively in pursuit of, the common goals that motivated their creation. When this happens, individual members will interact with group agents less in the role of active participants, and more in the role of affected subjects. Moreover, creating group agents with significant powers 
also increases the degree of affectedness and constraint to which non-members, along with members, risk subjection.

The political problem, then, is how to achieve two goals in conjunction: first, enabling groups of individuals to act collectively in order more effectively to pursue the goods that they share and strive for in common with others; while second, minimizing the extent to which individuals will need to interact with and relate to these group agents in the capacity of affected subjects, as distinct from active participants. ${ }^{15}$ The political purpose to which the republican ideal of non-domination is directed is that of preserving the functions of effective collective agencies within a social order, while enabling individuals to participate in these collective agencies as far as possible as insiders rather than outsiders - that is, as participants whose individuals goals are channelled in some way into the articulation and pursuit of the goals of powerful groups.

This view of the political problem to which the republican ideal is offered as a remedy provides the basis for the specific functional account of non-domination that I want to present here, in which non-domination is constituted by the functions of public power and antipower, performed in conjunction by distinct political agencies within a social order. Here public power and anti-power are conceived as distinct functional types

15 There are many ways of formulating moral arguments in favor of the view that this kind of function constitutes a moral "good." Pettit articulates a sophisticated consequentialist defence of his conception of non-domination in Republicanism. I also believe that a robust defense of my conception of non-domination can be mounted on the basis of a commitment to an appropriately formulated conception of individual autonomy (which incorporates a recognition of the ways in which individual autonomy can be exercised not only independently but also collectively). I cannot here present or defend a full account of the moral value attached to this political function; instead, I just note that I assume that the moral attractiveness of the republican ideal depends upon a successful account of this kind being available. 
of political agency, defined in terms of the differentiated functions that they perform in instantiating the republican ideal of non-domination.

Public power, on this republican conception, is that which functions to advance goals shared in common by a group's participants, through the creation of agencies with some special set of powers and competencies. When they are fully developed, agencies of public power will incorporate some mechanisms for the authorization (by group members) of some specialized set of individuals to act on behalf of the wider group as representatives. They will also generally incorporate some accompanying set of material and organizational structures, which function to support and facilitate the effective action in pursuit of collective goals by the group's representatives.

The character of such mechanisms and structures will vary according to the scale, complexity, and content of the goals being advanced in a given case. But examples of such structures include: material infrastructures such as those for processing and communicating complex forms of information, or for transporting products and people; organizational systems for strategically cultivating, coordinating, and deploying relevant individual skills and expertise; and underlying both of these, strategic distributions of material resources across the locations and populations where these structures are embedded, to enable the individuals occupying roles and performing tasks within these structures to do so effectively. Republicans have conventionally viewed the state as the paradigmatically 'public' political agent, since the state most straightforwardly fits the picture of this general functional account (though, as I will discuss later in this chapter, the state may not be the only kind of agent that qualifies as public in contemporary global politics). 
The special political powers constituted through such mechanisms and structures enable public political agencies to advance participants' goals more effectively than the set of individual group members could achieve acting independently. But these special powers also possess a special capacity to threaten individuals - both members and nonmembers - with arbitrary or alien forms of control. It is in response to this feature of public power that the functional demand for agencies of antipower arises. Agencies of antipower function as a kind of countervailing political force within the social order balancing against the force of public power, and countering the threat of its dominating control.

Since agencies of antipower are not burdened with the functional demand to supply any concrete social goods to the group (as are agencies of public power), they do not need to be constituted (as do agencies of public power) as specialised and structurally empowered elites acting merely "on behalf" or "in the name" of a group with shared goals. Instead, agencies of antipower are constituted to perform quite different functions: formulating and articulating the content of the group's common goods, through facilitating group dialogue, reasoning, and public communication; and channelling these understandings into the decision-making processes of agents of public power through some effective and public means. ${ }^{16}$ As Pettit puts it, " $[\mathrm{t}]$ he promotion of freedom as nondomination requires ... that something be done to ensure that public decision-making

${ }^{16}$ By "channeling" here, I mean to allow for means that involve both collaboration with and contestation of public power, and also for varying forms and degrees of institutionalisation. Pettit emphasizes the importance of contestation in elaborating his account of what it means for power to be non-arbitrary (Republicanism, p. 184), but it is important to recognize that in some cases agents of public power might in fact be welcoming of this input, and in such cases collaborative rather than contestatory means for channeling ideas and interests into public decision-making processes may play an important role in discharging the general function of antipower. 
tracks the interests and the ideas of those citizens whom it affects." ${ }^{17}$ In response to this demand, antipower is comprised of the various social agencies that function to ensure, to the greatest possible degree, that the interests and ideas of those subjected by public power remain alive and active in the formulation of public political decisions.

Although strongly empowered individual agents may in some circumstances function as important agents of anti-power, in most cases collective forms of political agency will be required to perform the functions of antipower effectively - in counteracting the threat of domination emanating from large-scale, complex, and wellresourced agencies of public power. Democratic "publics" or "demoi" the strongest sources of antipower, where such agencies can be successfully constituted through the establishment of mechanisms for democratic deliberation and social choice. Democratic agencies have particular strength because they are - in virtue of the democratic norms that shape their constitution - strongly participatory and egalitarian. But other kinds of social agencies can also perform the functions of antipower, albeit in more partial ways.

Of particular importance in this latter category are publicly-oriented (albeit not fully participatory or egalitarian) group agencies constituted within what is often called the sphere of "civil society" - in particular those advocacy groups that contribute to collective social dialogues in which common goals are explored and articulated, as well as engaging directly, through contestatory or collaborative processes, with agents of public power to channel these goals into public decision-making. Less publicly-oriented

\footnotetext{
${ }^{17}$ Pettit, Republicanism, p. 184.

${ }^{18}$ For an important republican discussion of the pluralism of democratic "demoi" in contemporary global politics, see James Bohman, Democracy across Borders: From Dêmos to Dêmoi (Cambridge, MA: MIT Press, 2007).
} 
groups within "civil society" - what are now often called "interest groups," and which are linked to what James Madison called "factions"19 - can also perform some more limited functions of antipower, in particular in situations where conflicting interest groups or factions are sufficiently evenly matched in social power that they can counter each other's attempts to capture public political agencies as instruments for their factional interests. $^{20}$

\section{Strengthening Agents of Antipower in Support of Non-Domination: The Role and}

\section{Limits of Institutional Design}

So far I have described the political functions that must be performed by agencies of public power and antipower operating in conjunction within the social order, in order for the ideal of non-domination to be instantiated. With an understanding of these functions in hand, we can begin to tackle the crucial institutional question of interest to republicans aiming to reduce domination within the global order: what can be done, via global institution building, to create and strengthen the functions of antipower, in its relationship with public power at the global level?

Before getting to a discussion of concrete and specific institutional design problems raised by this question, it is helpful to raise a more general question about the role and limits of institutions in constituting the functional agencies of public power and antipower. This question is important since any practical project aimed at building

\footnotetext{
${ }^{19}$ Alexander Hamilton, John Jay, and James Madison, The Federalist Papers, ed. Clinton Lawrence Rossiter (New York: New American Library, 1961).

${ }^{20}$ A Madisonian separation of powers is a familiar institutional means of harnessing and augmenting this more general social function of antipower that can be discharged through interactions among competing interest groups. See ibid.
} 
institutions must begin with a clear understanding of the scope of what such institutions can be expected to achieve and transform within the global social order, and conversely the range of non-institutional facts that must be accommodated and adjusted for in the construction of concrete institutional proposals. If it is the case, as I will argue, that the social agencies functioning as antipower cannot be wholly constituted through the structures of political institutions, but rather are constituted also in part by some set of independent non-institutional social facts, then the character of these independent facts must be clearly identified and adjusted for in the formulation of republican institutional proposals.

It is my claim that although agencies of public power and antipower cannot function effectively without institutions of the right kinds in place to enable and promote their functioning, we cannot regard public power or antipower as wholly institutionally constituted. Rather, they are constituted in part also by contextually variable noninstitutional facts, of kinds that I will specify, which lie beyond the scope of effective strategic institutional control, and to which republican institution builders must be responsive if they are to succeed in creating functionally effective agencies of antipower in a given context.

Let us consider first the dimensions in which agencies of public power and antipower are institutionally constituted. First, in the constitution of a group agent in general, the roles played by individuals can be variable, depending very much on the particular goals that the group agent is pursuing, and the relevant features of the environment in which it acts. List and Pettit note this variability: 
When a group of individuals form an agent, they may relate to one another in a more or less coordinate manner, with each playing a similar role. Alternatively, they may be divided up into different subgroups, each with its distinctive tasks. In either case their relations with one another may involve a hierarchy or a more or less egalitarian arrangement. ${ }^{21}$

When the goals being pursued or the environment in which they are being pursued are complex, then group agents will usually need to be constituted with correspondingly complex divisions of labor among individuals - to develop expert understandings of various different elements of the goals being pursued and of the environment of action, and to perform different specialized tasks in the overall complex processes of pursuing strategies to pursue goals, and carrying these strategies out. Institutions are often crucial to constituting group agents, insofar as they operate to define these differentiated roles within the group, and to allocate such roles to different individuals through suitable rules and procedures. Institutions can also play a crucial role in constituting group agents insofar as they embody structures through which various social resources are distributed, and as such they can operate to help allocate the necessary resources to individuals in different roles to enable them to perform their specialized functions effectively.

For agencies of public power, institutions articulate the complex webs of organizational norms and rules that are required to facilitate the production, distribution, and mobilization of resources, as well as the cultivation and deployment of expertise, that are necessary to perform functions of government or governance in particular

${ }^{21}$ List, Group Agency, p. 32. 
environments and issue-areas. In the case of states, these constitute the various roles and institutional powers within the functional domains of legislative, executive, and judicial public power. In the case of non-state forms of public power - those engaged in forms of what is commonly called "governance" activity - the range of institutionally constituted roles and rules is more contextually variable, but the role of institutions in constituting their functions is no less significant for that.

For agencies of antipower, institutions articulate a different set of norms and rules for participants, commensurate with the distinct functions that individuals are required to perform as participants in these group agencies. Most importantly, they articulate the norms and rules that constitute practices of collective reasoning and deliberation, through which collective goals can emerge and receive clear articulation. Institutional norms and rules can also help create clear procedures for the formation of decisive collective intentions (about what should be done by agencies of public power). Examples of these include the aggregative procedures through which democratic group decisions are sometimes produced, or procedures for authorizing certain individuals or smaller groups to make decisive judgments on behalf of the group and in the group's name, in light of the various reasons emerging as salient through collective reasoning and deliberation. Some kinds of procedures for authorizing decision-making may count as democratic when compliant with appropriate representative norms - while others may fall short of democratic standards but still be sufficient to enable effective functioning of the group as a collective agent.

Although the functions of antipower will mainly need to be performed by collective agents, if they are successfully to rival and balance against the often significant 
powers of public political agencies, individuals can also - albeit in more limited ways serve to engage directly with agencies of public power to counteract the force of their power, and to channel wider interests into their decision-making processes. Institutions can play a role here too in helping empower individuals to act as important agents of antipower, through allocating resources to individuals that help foster their political skills and capacities, and by creating rules and roles that offer them protections against the arbitrary exercise of power by others. ${ }^{22}$

But there are also significant limits to the work that institutions can do to constitute group agencies with capacities to perform functions of public power and antipower effectively. To understand the character of these limits, it is important first to understand that agencies of public power and antipower are constituted not only by structures of rules, of the kind that are put in place by institutions, but also by certain kinds of material structures and cultural artifacts, which help ensure that actors in given roles have the requisite knowledge, capacities, and resources to discharge their designated functions as part of the function of the whole group agent.

Important material structures in the case of public power include resources and infrastructures such as government buildings, information systems and technologies, and technologies, equipment and other resources for performing the myriad specialized tasks assigned to different agencies within governmental or governance structures. In the case of antipower, the most material structures are the material dimensions of communicative infrastructures that enable groups of individuals to reason and deliberate together. Certain basic cultural artifacts will also need to be available to enable the functioning of group

\footnotetext{
${ }^{22}$ Pettit emphasizes the importance of institutions that he describes as protective, regulatory, and empowering, in this connection (Republicanism, pp. 589-90).
} 
agencies of both kinds - most importantly shared languages, but also some wider set of shared meanings and understandings that are pre-requisites for the recognition of common interests and goals among members of the group, and for coordinated social action in support of institutions with specified social goals.

Institutions can certainly support the development of these requisite material structures and cultural artifacts to some degree, by strategically creating and resourcing new roles and rules that are likely to encourage their development and production over time. But institutions cannot ever be expected to produce, or steer the production of, all or even most of the important material structures and cultural artifacts within a social order that shape the capacities of particular groups of individuals to join together as agents with particular specified functions. The simple reason for this is that a certain set of non-institutional material structures and cultural artifacts must already be in place to constitute the shared understandings of common interests and goals, and the basic capacities for collaborative and cooperative action, which are required to establish institutions in the first place.

Institutions can serve to reinforce, develop, and systematize these shared understandings and structures, and in doing so to generate the more rational and functionally effective forms of collective behavior that meet the criteria for what we can call group agency. And the causal effects of these institutions upon their social environment can also alter, over time, the character of the material structures and cultural understandings that initially gave rise to earlier instantiations of the institutions. In doing so, they can create impetus for the groups acting through the institutions to adjust institutional goals, and accordingly reform the structure of roles and rules to function 
more effectively in support of the new goals. (Though the causal relationships involved in producing these effects will generally be so complex that the level of strategic control over the effects, by institutional designers, will often be low.)

But despite the undoubtedly significant and transformative effects that institutions can have on social orders, one very plain constraint will always remain: institutions cannot have goals that are independent from those held by the agents that establish them. As such, the content of those goals, and the elements of collective agency that are necessary to articulate and to pursue them through institutions, embody those elements of the social order that institutions cannot aim to transform, but rather must take as givens starting points - for any institution building project.

These general arguments have significant implications for our understandings of what can and cannot be done via global institution building, to create and strengthen the functions of antipower, in its relationship with public power, at the global level. What is called for in the design of republican political institutions for global politics is a strong responsiveness to material structures and cultural artifacts of relevant kinds that shape and limit the potentialities for agencies of public power and antipower to develop and function effectively. Republican institutions can be built with the aim of nurturing and strengthening embryonic agencies of public power and antipower, by creating roles and rules and allocating resources in helpful ways. But they cannot aim to design institutions to constitute agencies of public power and antipower with the expectation that the project of institution building is one of devising blueprints for social order - as though starting, like the design project of an architect or engineer may sometimes do, with a blank page and an empty lot. 


\section{Republican Institution Building in the Context of Global Political Pluralism}

With the general approach to republican institution building that is recommended by the arguments I have presented so far in hand, we are now in a position to consider what prescriptions follow for more concrete contemporary dilemmas of global institutional development and design. The basic institutional problem for republicans is that of identifying what strategies can best steer global institutional development in ways that are likely to strengthen agencies of antipower in their domination-combating functions. In order to identify these strategies, we must address the following two questions.

First, what agencies of public power and antipower currently exist at the level of global politics, in fully developed or embryonic functional forms, of the kind that could provide the sociological materials for republican institutions to go to work on, with the goal of strengthening functions of antipower in its relationship with public power?

Second, what kinds of institutions will be effective in strengthening the functions of agencies of antipower in relation to public power in these existing structural forms, in different contexts within the contemporary global social order? These are both very large questions, and it is not possible within the constraints of this chapter to answer them in anything approaching a comprehensive way; but some general and illustrative observations can be presented in relation to each.

To begin, let us consider the present structure of global public power. Traditionally, republicans have linked the concept of public power to the specific institutional structures associated with statehood. State institutions have been thought of 
as uniquely - sometimes even by definition - "political" and "public." In parallel to this, other institutional forms - such as markets, corporations, processes of economic "production," institutionalised "supply chains," "civil associations," "social movements," NGOs, and so on - have been presumed to be "private." But once we adopt a functional rather than an institutional understanding of republican public power - as I have argued here that we should do - it becomes clear that states are no longer the only kind of agencies that perform the functions characteristic of public power. More specifically, states are no longer the only agencies that possess significant powers to advance important shared goals within those groups in the name of which they act, as well as to constrain the choices of affected populations.

Under existing conditions of globalization, the reality now is that non-state actors such as multinational corporations, non-governmental organisations (NGOs), and hybrid institutional actors constituted by both state and non-state actors, now wield many of these forms of decision-making power (in fields of law-making, economic development, public service-provision, and so on), alongside a plurality of states. ${ }^{23}$ As I have discussed in more depth elsewhere, the structure of public power within the existing global order can be characterised as pluralist - by which I mean that public power is exercised by myriad separate state, inter-governmental, and non-state agents operating at multiple and

\footnotetext{
${ }^{23}$ For more detailed accounts of the various and significant accounts of non-state power, please see Susan Strange, "The Declining Authority of States," in The Global Transformations Reader: An Introduction to the Globalization Debate, eds. David Held and Anthony McGrew (Malden, MA: Blackwell, 2000); David Held, Democracy and the Global Order: From the Modern State to Cosmopolitan Governance (Cambridge: Polity Press, 1995); A. Claire Cutler and Virginia Haufler, Private Authority and International Affairs (Albany: State University of New York Press, 1999); Nico Krisch, Beyond Constitutionalism: The Pluralist Structure of Postnational Law (Oxford: Oxford University Press, 2011); Terry Macdonald, Global Stakeholder Democracy: Power and Representation Beyond Liberal States (Oxford: Oxford University Press, 2008).
} 
overlapping jurisdictional levels, rather than unified through any one supreme global political authority or hierarchy of constitutional principles. ${ }^{24}$

As I argued above, a crucial question for republican institution builders confronted with these plural agencies of public power must be: how malleable are these configurations of public power - and to what extent, and over what kind of timeframe, are we likely to be stuck with them in roughly this form? It will certainly be possible to reconfigure the structure and functions of these agencies of public power to some degree - through various strategies of public institution building and reform. However, the sheer complexity of the causal relationships that combine to generate the functions of public power that are discharged through these agencies is so high that strategic interventions to alter the structure of these agencies can only realistically be achieved partially, incrementally, and over very long timeframes. Recall that agencies of public power are constituted not only by institutions but also complex configurations of functionally effective material technologies and infrastructures, structural resource distributions, concentrations of relevant information and expertise, and the shared background cultural understandings that enable the many individuals that participate in these complex group agencies to recognise shared interests and goals and coordinate their communication and action in pursuit of them.

\footnotetext{
${ }^{24}$ Kate Macdonald and Terry Macdonald, "Democracy in a Pluralist Global Order: Corporate Power and Stakeholder Representation," Ethics \& International Affairs 24, no. 1 (2010); Macdonald, Global Stakeholder Democracy; Philip Cerny, "Plurality, Pluralism and Power: Elements of Pluralist Analysis in an Age of Globalization," in Pluralism: Developments in the Theory and Practice of Democracy ed. Rainer Eisfeld (Opladen and Farmington Hills: Barbara Budrich Publishers, on behalf of the International Political Science Association, Research Committee No. 16 [Socio-Political Pluralism], 2006); Philip Cerny, "Globalization and the Erosion of Democracy," European Journal of Political Research 36, no. 1 (1999): 1-26.
} 
Effective strategic interventions to change the structure and functions of agencies of public power can only occur to the extent that is possible for political actors to grasp the complex empirical detail of how the various constitutive elements interact to create the relevant functions, as well as what interventions would be effective in bringing about the relevant changes. Performing these feats would require the capacity not only to acquire and analyze vast quantities of information, but also to undertake enormous creative and imaginative leaps of strategic innovation, at the levels of both technological and organizational design, of a kind that I assume it is unrealistic to expect either of affected populations, mobilizing to transform public power via organized agencies of antipower, or of 'expert' republican institutional designers, working with philosophical and social scientific tools. If this assumption is a reasonable one, then it follows that republican institution builders should limit their ambitions with respect to the extent to which the global order can be transformed through the development of republican political institutions. ${ }^{25}$

Let us turn next, then, to examine the character of agencies of antipower within the existing global order. The existing configuration of agencies of antipower within the global political order is - just like the configuration of agencies of public power pluralist in character. Parallel to the idea of pluralism in relation to public power, this pluralism means that the functions of antipower are performed by myriad separate social agencies comprised of distinct though sometimes overlapping population groups,

\footnotetext{
${ }^{25}$ This modesty of transformative ambition that I am advocating is, I believe, shared by Pettit in his "Republican Law of Peoples," insofar as he begins by accepting as given the prominence of states as public political actors within the international system. I depart from him only in insisting that a proper responsiveness to existing social facts requires us to recognise a range of non-state actors, also, as agents of public power within a contemporary republican order.
} 
operating within multiple distinct though sometimes overlapping issue areas, and engaging with various, sometimes overlapping, sets of public political agencies. ${ }^{26}$ The social agencies that work to challenge and counteract public political power - and to channel wider and shared social interests into its decision-making processes - include the following.

Most straightforwardly, democratically constituted groups within established states (traditional democratic “demoi”), or other national or subnational groups constituted as group agents through the requisite (albeit not fully democratic) communicative and decision-making structures, can function as sources of antipower in relation to global as well as domestic agencies of public power. They can do so when they mobilize in direct political engagement with agents of public power operating in the global domain - whether corporations, other states, or international or non-governmental public actors. Sometimes - in states where public agencies are strongly representative these nationally bounded and sub-national group agents can channel their goals and apply pressure on external public actors through delegating state agencies to do so on their behalf through instruments of foreign policy. But where states are less representative, or when domestic constituencies are more divided, these groups sometimes find or create alternative conduits for channeling their goals into public global decision-making - such as delegations of individual parliamentarians, representatives of political parties, or representatives of domestically constituted advocacy groups.

\footnotetext{
${ }^{26}$ Pluralism in the domain of antipower is contrasted with the kind of unified "demos" that is tasked with performing these functions within some variants of democratic thought.
} 
Myriad transnational advocacy groups - most prominently international NGOs, but also looser campaign coalition groups, and more specialized transnational agencies such as international trade unions - also operate alongside these domestically constituted groups. These perform functions of antipower by channeling a wide range of goals and interests shared in common by populations across state boundaries into the decisionmaking processes of powerful public actors such as corporations and International Organizations. Their strength and success in doing so is widely variable across different issue areas, and across different relationships and cases of political engagement. But the general character of their functions as agencies of antipower within the global political order are nonetheless readily recognizable.

As in the case of public power, a crucial question for republican institution builders confronted with these existing plural agencies is: how will attempts to reconfigure and strengthen these agencies of antipower via republican institution building projects be constrained by the background material and cultural structures that partially constitute them? The character of these constraints can be inferred from the highly uneven patterns in which existing agencies of public power have developed. Functionally effective agencies of antipower do not match or track the configurations of objective interests that groups within the global order may share in common. Rather, their development has tended to track the various pre-existing material and cultural structures (communicative and other social infrastructures, resource distributions, shared cultural understandings, and so on) that are required to enable groups with common interests to recognise and articulate shared goals, and to advance them collectively through political action. 
More concretely, this means that antipower has tended to develop in ways that build on existing established infrastructures within civil society - established trade unions, community associations, domestic political parties and lobby groups, etc. - and it tends to be stronger within issue areas, and in relation to interest groups, who have better access to the relevant resources, infrastructures, and so on. The uneven development of public power against these varying background conditions can thus be adduced in support of the more general claim that the constraints on institution building projects are real and significant, and must be adequately accommodated in the development of republican institutional prescriptions.

These constraints do not mean, however, that the development of republican institutions cannot serve to reconfigure and strengthen existing global agencies of antipower in any significant ways. Rather, what follows is that institution building projects must proceed with a clear understanding of these constraints, so that these can be suitably adjusted for within institutional models - thus enabling these institutions to be strategically targeted and designed to strengthen the functions of antipower as effectively as possible under prevailing background conditions. How, then, can this be done? At the most general level, we can say that the constraints on how far and how readily existing configurations of public power and antipower can be altered through strategic institutional interventions are sufficient to conclude that - at least in the foreseeable future - both public power and antipower are likely to retain a broadly pluralist structure. As a result, republican institutional interventions must begin with an acceptance of this political pluralism, and tailor institutional proposals to this reality. 
The concrete implications of these arguments for the kinds of institutions that republicans should support and promote will be highly contextually variable. As such, a fully satisfying elaboration of the practical implications of the theoretical arguments I have presented here would require detailed examination of specific institutional problems and cases, of a kind that is beyond the scope of the present chapter. For the present purposes, it will have to suffice to present some cursory and illustrative observations about the implications of these arguments, focusing on some familiar and prominent controversies about global institutional design concerning the appropriate interpretation and application of norms of democracy and accountability.

One significant application of these arguments is to dilemmas concerning the design and development of democratic institutions beyond the level of the state - in particular, how the 'boundaries' of democratic decision-making institutions should be delineated. While many powerful and important arguments have been advanced in favor of developing certain "cosmopolitan" democratic institutions, ${ }^{27}$ adapting many institutional features of state-based democratic practices to a global context, the arguments presented here suggest that at least some institutional features of an emerging global democratic order should be developed to reflect the pluralism of the existing structures of public power and antipower. The pluralist model requires that democratic boundaries should be determined by locating existing agencies of political power within the global social order, and then working towards their incremental democratic cooptation and control by strengthening and expanding the functions of existing agencies of

\footnotetext{
${ }^{27}$ David Held, Democracy and the Global Order; Daniele Archibugi, The Global Commonwealth of Citizens: Towards Cosmopolitan Democracy (Princeton: Princeton University Press, 2008).
} 
antipower - in accordance with democratic norms of inclusion, representation, and so on. ${ }^{28}$

The arguments presented here about the limits of institutional design in constituting agencies of public power and antipower have some further implications for dilemmas about appropriate policies of democracy promotion and democratic interventionism in international politics. The dilemmas here concern the extent to which policy interventions to promote democracy - ranging from military intervention to promote "regime change" and the establishment of democratic institutions, through to less coercive but similarly "top-down" and strongly "institutional" approaches to democracy promotion, focused on establishing and strengthening the operation of democratic constitutions - are likely to be successful.

Since agencies of antipower are constituted not only by the right institutions, but also by congenial background material structures and cultural artifacts which cannot in turn be wholly reconfigured through strategic institutional interventions, projects to bring about democratic "regime change" or to strengthen democratic practices in areas of weakness cannot disregard these structures but must find ways to build institutions that can function within the constraints that they impose in particular contexts. Once we recognize democratic antipower as a form of social agency - not a mere institutional structure - it is easier to see why democracy can rarely be imposed from outside a social order, through external institution building interventions. Policies for the promotion of democracy, then, should aim instead at locating existing agencies of antipower, and

\footnotetext{
${ }^{28}$ Macdonald, Global Stakeholder Democracy; Macdonald, "Democracy in a Pluralist Global Order"; Bohman, Democracy across Borders.
} 
nourishing and cultivating their growth, through strategies that are more developmental and incrementalist in character.

A final set of institutional dilemmas on which these theoretical arguments may have some bearing is concerns the broader question: what responsibilities should powerful non-state actors, such as powerful international NGOs and multinational corporations, have for promoting non-domination? And how should their responsibilities be differentiated from the responsibilities of this kind accorded to states? This general question translates into a range of more specific dilemmas concerning the public status and political responsibilities of powerful non-state actors. These include current and ongoing debates about whether and how international law should accord any responsibilities for upholding human rights standards, ${ }^{29}$ and familiar debates about the forms of social and political "accountability" and "legitimacy" that should be demanded from powerful corporations and NGOs. ${ }^{30}$ Whereas it has been traditional to argue that public responsibilities for promoting non-domination (through human rights protections, the establishment of accountability practices, and so on) fall exclusively to states, the arguments that I have presented here about the status of powerful non-state actors as agencies of public power lends support to the view that they too should be accorded strong public responsibilities and held firmly to account in discharging them.

\footnotetext{
${ }^{29}$ John Ruggie, "Interim Report of the Special Representative of the Secretary-General on the Issue of Human Rights and Transnational Corporations and Other Business Enterprises," UN Coc E/CN.4/2006/97 (2006).

${ }^{30}$ Macdonald, Global Stakeholder Democracy; Michael Edwards, David Hulme, and Save the Children Fund (Great Britain), Non-Governmental Organisations: Performance and Accountability: Beyond the Magic Bullet (London: Earthscan, 1995).
} 


\section{Conclusions}

In this chapter I have elaborated an account of non-domination as a political ideal that combines normative individualism with a recognition of the functional reality and political significance of group agents within the social world inhabited by individuals. On this reading of the republican ideal, non-domination is valued for the goods that individuals enjoy in virtue of it, but consists in a particular functional configuration of the relationships of power between individuals and group agencies within the social order. It is constituted by the dual functions of public power and anti-power, operating together to combat the alien or arbitrary control of individuals by agents (sometimes individuals but most importantly powerful groups) within the social order.

This has important implications for our understandings of the concrete institutional projects that republicans should aim to advance. Strategically formulated republican institutional projects can do a certain amount to make existing agencies of public power more effective and to expand and reform some of their functions. They can also contribute to strengthening agencies of anti-power, by allocating resources, creating institutional channels for communication, establishing procedures for joint decisionmaking, and so on. But institution building projects must always be structured around, and engaged with the contextual particularities of, the agencies of public power and antipower that already exist within the global social order, and are embedded in those background material and cultural structures that are beyond the scope of strategically rational institutional control.

On this agent-centric formulation of the ideal of non-domination, we may think then that the appropriate metaphor for republican institution-building is not the 
objectifying one of institutional design - which implies a practical focus on institutional engineering and architecture; rather, it is the organic one of cultivating institutional growth. Overall, this should be taken to encourage a republican approach towards institution building that is characterized by an attitude of developmental nurturing rather than one of interventionist control.

\section{Bibliography}

Archibugi, Daniele. The Global Commonwealth of Citizens: Towards Cosmopolitan Democracy. Princeton: Princeton University Press, 2008.

Bohman, James. Democracy across Borders: From Dêmos to Dêmoi. The MIT Press, 2007.

Cerny, Philip. "Globalization and the Erosion of Democracy." European Journal of Political Research 36, no. 1 (1999): 1-26.

_. "Plurality, Pluralism and Power: Elements of Pluralist Analysis in an Age of Globalization." In Pluralism: Developments in the Theory and Practice of Democracy edited by Rainer Eisfeld, 81-111. Opladen and Farmington Hills: Barbara Budrich Publishers, on behalf of the International Political Science Association, Research Committee No. 16 [Socio-Political Pluralism], 2006.

Cutler, A. Claire, Virginia Haufler. Private Authority and International Affairs. Suny Series in Global Politics. Albany: State University of New York Press, 1999.

Edwards, Michael, David Hulme, and Save the Children Fund (Great Britain). NonGovernmental Organisations: Performance and Accountability: Beyond the Magic Bullet. London: Earthscan, 1995.

Hamilton, Alexander, James Madison, John Jay. The Federalist Papers. Edited by Clinton Lawrence Rossiter. New York: New American Library, 1961.

Held, David. Democracy and the Global Order: From the Modern State to Cosmopolitan Governance. Cambridge: Polity Press, 1995.

- Democracy and the Global Order: From the Modern State to Cosmopolitan Governance. Cambridge: Polity, 1995.

Krisch, Nico. Beyond Constitutionalism: The Pluralist Structure of Postnational Law. Oxford: Oxford University Press, 2011.

List, Christian, and Philip Pettit. Group Agency: The Possibility, Design, and Status of Corporate Agents. Oxford: Oxford University Press, 2011.

Macdonald, Kate and Terry Macdonald. "Democracy in a Pluralist Global Order: Corporate Power and Stakeholder Representation." Ethics \& International Affairs 24, no. 1 (2010): 19-43. 
Macdonald, Terry. Global Stakeholder Democracy: Power and Representation Beyond Liberal States. Oxford: Oxford University Press, 2008.

Pettit, Philip. "Freedom as Antipower." Ethics 106, no. 3 (1996): 576-604.

Pettit, Philip. Republicanism: A Theory of Freedom and Government. Oxford: Oxford University Press, 1999.

Pettit, Phillip. "A Republican Law of Peoples." European Journal of Political Theory 9, no. 1 (2010): 70-94.

Pettit, Philip. "The Republican Law of Peoples: A Restatement." In Domination and Global Political Justice: Conceptual, Historical and Institutional Perspectives. Edited by Barbara Buckinx, Jonathan Trejo-Mathys, and Timothy Waligore (Routledge: 2014).

Pogge, Thomas. Realizing Rawls. Ithaca: Cornell University Press, 1989.

Ruggie, John. "Interim Report of the Special Representative of the Secretary-General on the Issue of Human Rights and Transnational Corporations and Other Business Enterprises." UN Coc E/CN.4/2006/97 (2006).

Strange, Susan. "The Declining Authority of States." In The Global Transformations Reader: An Introduction to the Globalization Debate, eds., by David Held and Anthony McGrew (Malden, MA: Blackwell, 2000). 


\section{University Library}

\section{- $\mathrm{M}$ IIN E R VA A gateway to Melbourne's research publications}

Minerva Access is the Institutional Repository of The University of Melbourne

Author/s:

MACDONALD, T

Title:

Antipower, Agency, and the Republican Case for Global Institutional Pluralism

Date:

2015

Citation:

MACDONALD, T. (2015). Antipower, Agency, and the Republican Case for Global

Institutional Pluralism. Buckinx, B (Ed.). Trejo-Mathys, J (Ed.). Waligore, T (Ed.). Domination and Global Political Justice; Conceptual, Historical and Institutional Perspectives, (1st), 66, pp.291-312. Routledge.

Persistent Link:

http://hdl.handle.net/11343/292059 